\title{
TAKING STOCK: The Constructivist Research Program in International Relations and Comparative Politics
}

\author{
Martha Finnemore ${ }^{1}$ and Kathryn Sikkink ${ }^{2}$ \\ ${ }^{1}$ Political Science Department, Funger Hall 625, George Washington University, \\ Washington, D.C.20052; e-mail: finnemor@gwu.edu \\ ${ }^{2}$ Department of Political Science, University of Minnesota, 267 19th Avenue S., \\ Minneapolis, Minnesota 55455; e-mail: ksikkink@polisci.umn.edu
}

Key Words constructivism, ideas, identity, norms, culture, beliefs

- Abstract Constructivism is an approach to social analysis that deals with the role of human consciousness in social life. It asserts that human interaction is shaped primarily by ideational factors, not simply material ones; that the most important ideational factors are widely shared or "intersubjective" beliefs, which are not reducible to individuals; and that these shared beliefs construct the interests of purposive actors. In international relations, research in a constructivist mode has exploded over the past decade, creating new and potentially fruitful connections with long-standing interest in these issues in comparative politics. In this essay, we evaluate the empirical research program of constructivism in these two fields. We first lay out the basic tenets of constructivism and examine their implications for research methodology, concluding that constructivism's distinctiveness lies in its theoretical arguments, not in its empirical research strategies. The bulk of the essay explores specific constructivist literatures and debates in international relations and comparative politics.

\section{INTRODUCTION}

In his 1988 presidential address to the International Studies Association, Robert Keohane noted the rise of a new approach to international politics and put forward a challenge: Success or failure of the new approach would depend on its ability to inspire and support a vigorous program of empirical research (Keohane 1988). ${ }^{1}$ Thirteen years later, we believe that this challenge has been easily met. Constructivist empirical research is thriving in the study of international affairs and has been applied in virtually every issue of interest to scholars. Indeed, ten

\footnotetext{
${ }^{1}$ Keohane referred to this new approach as a "reflective" approach; since that time, the standard name has become "constructivism."
} 
years after Keohane's challenge, he, Katzenstein, and Krasner acknowledged that constructivism and rationalism provide the major points of contestation shaping the field in years to come (Katzenstein et al 1999).

In this essay, we take stock of the constructivist research program. Several excellent works have now been written that survey the range of constructivist theoretical arguments (Adler 1997, Price \& Reus-Smit 1998, Ruggie 1998, Wendt 1999). However, the empirical research program, on which the "success" of this theorizing depended in the eyes of many, has received much less systematic treatment. Since it was unclear to Keohane and others how scholars working in a constructivist vein would or could carry out empirical research, how did they solve these problems? What kinds of research have emerged? What have been the foci of this research, what have been its strengths and weaknesses, and where is it going?

To address these questions, we survey constructivist empirical research with several purposes in mind. We begin with a brief discussion of the core features of constructivist theorizing that have informed this research. In the second section, we take up the question of whether there is a "constructivist methodology" for empirical research. One of the concerns about early constructivist writings was that they provided little guidance for developing concepts and methods of empirical analysis. Scholars have now responded to these problems in various ways, and we survey the results of their work. We conclude that constructivist analysis is compatible with many research methods currently used in social science and political science. Constructivism's distinctiveness lies in its theoretical arguments, not in its empirical research strategies.

The next section reviews constructivist empirical research in international relations (IR). We organize this review around major research questions that have motivated constructivists and note trends in IR empirical research that build bridges to comparative politics by inviting, and even requiring, comparative politics research to substantiate claims. Comparativists have long been interested in questions of culture, ideas, and identity, but few comparative authors identify themselves as constructivists. Using the core features of constructivism as our criteria, we identify and discuss a range of works in comparative politics that could be called constructivist. We conclude by exploring the ways in which constructivism, which arose in the IR field, opens new connections between IR and comparative politics.

\section{CORE FEATURES OF CONSTRUCTIVISM}

"Constructivism is about human consciousness and its role in international life" (Ruggie 1998:856). Constructivists focus on the role of ideas, norms, knowledge, culture, and argument in politics, stressing in particular the role of collectively held or "intersubjective" ideas and understandings on social life. Specifically, constructivism is an approach to social analysis that asserts the following: (a) 
human interaction is shaped primarily by ideational factors, not simply material ones; $(b)$ the most important ideational factors are widely shared or "intersubjective" beliefs, which are not reducible to individuals; and (c) these shared beliefs construct the interests and identities of purposive actors (Adler 1997, Price \& Reus-Smit 1998, Ruggie 1998, Wendt 1999). Constructivism focuses on what Searle (1995) has called "social facts"- - things like money, sovereignty, and rights, which have no material reality but exist only because people collectively believe they exist and act accordingly. Understanding how social facts change and the ways these influence politics is the major concern of constructivist analysis. Constructivism's main analytical competitors have thus been approaches of two kinds: (a) materialist theories, which see political behavior as determined by the physical world alone, and $(b)$ individualist theories, which treat collective understandings as simply epiphenomena of individual action and deny that they have causal power or ontological status. All constructivist analyses use an ideational ontology and holism in some way.

Constructivism is a differnt kind of theory from realism, liberalism, or marxism and operates at a different level of abstraction. Constructivism is not a substantive theory of politics. It is a social theory that makes claims about the nature of social life and social change. Constructivism does not, however, make any particular claims about the content of social structures or the nature of agents at work in social life. Consequently it does not, by itself, produce specific predictions about political outcomes that one could test in social science research. Constructivism in this sense is similar to rational choice. Like rational choice, it offers a framework for thinking about the nature of social life and social interaction, but makes no claims about their specific content. In a rational choice analysis, agents act rationally to maximize utilities, but the substantive specification of actors and utilities lies outside the analysis; it must be provided before analysis can begin. In a constructivist analysis, agents and structures are mutually constituted in ways that explain why the political world is so and not otherwise, but the substantive specification of agents and structures must come from some other source. Neither constructivism nor rational choice provides substantive explanations or predictions of political behavior until coupled with a more specific understanding of who the relevant actors are, what they want, and what the content of social structures might be.

Rational choice has been used extensively in the service of materialist and individualist theories such as neorealism and neoliberalism, in which the relevant actors are states who want material security and/or wealth. The substantive predictions of these theories are not predictions of rational choice, however, but of the political arguments that inform it. Constructivist frameworks have been joined to a variety of substantive specifications with diverse results (reviewed below). The particular findings of these efforts are not the substance of constructivism, however, nor are predictions that flow from these findings the predictions of constructivism any more than Waltzian realism is the prediction or singular result of rational choice. They are the findings and predictions of scholars, which flow from their chosen substantive starting point for constructivist analysis. 


\section{LOGIC AND METHODS OF INQUIRY}

Constructivism's core assumptions have shaped its empirical research program in several important ways. They have shaped the kinds of questions constructivists tend to ask by opening up for inquiry issues that other approaches had failed to engage. Since, by ontological assumption, constructivists understand that actors are shaped by the social milieu in which they live, one obvious research question for them is: How does this shaping happen and with what results? Unlike proponents of materialist and utilitarian theories, constructivists cannot take identities and interests for granted, and understanding the processes by which they originate and change has been a big part of the constructivist research program. To frame research designs on these questions, scholars have supplemented constructivism's minimalist social-theoretic claims with a variety of more specific, often more substantive, theories about the mutual constitution process and the behavior that results from it. Constructivists have explored Foucauldian analyses of the power of discourse to understand these processes (Ferguson 1990; Keeley 1990; Price 1995, 1997). They have explored theories of agency and culture (Bukovansky 2001), Goffman-type analyses about self-presentation in public life (Barnett 1998), Karl Deutsch's notions about security communities (Adler \& Barnett 1998), theories about organizational behavior (Finnemore 1996a,b; Barnett \& Finnemore 1999), social movement theory (Smith et al 1997, Keck \& Sikkink 1998), Habermasian theory about communicative action (Risse 2000, Checkel 2001), and mediation theory (Ratner 2000), to name a few.

Their focus on these process questions, on how identities and interests are created, has led many constructivists to think more broadly about the nature of causality and explanation than some of their rationalist or utilitarian colleagues. Constructivists are skeptical about claims to all-encompassing truth [what Price \& Reus-Smit (1998) call "Big-T" claims] and instead produce and evaluate "small-t" contingent claims. Such partial and contingent claims may still constitute causal explanation, albeit in a somewhat different sense than realists or liberals understand causality. For constructivists, understanding how things are put together and how they occur is not mere description. Understanding the constitution of things is essential in explaining how they behave and what causes political outcomes. Just as understanding how the double-helix DNA molecule is constituted materially enables understandings of genetics and disease, so, too, an understanding of how sovereignty, human rights, laws of war, or bureaucracies are constituted socially allows us to hypothesize about their effects in world politics. Constitution in this sense is causal, since how things are put together makes possible, or even probable, certain kinds of political behavior and effects (Wendt 1998, Barnett \& Finnemore 1999). Because they are permissive and probabilistic, however, such explanations are necessarily contingent and partial — they are small-t truth claims. However, the fact that constitutive explanations have causal properties means that the distinction between constitutive explanations and other forms of explanation may not be sharp in practice, particularly in empirical work. 
Constructivism's core assumptions have also shaped the methods by which constructivists go about answering their questions. Constructivists need methods that can capture the intersubjective meanings at the core of their approach. Constructivists recognize that all research involves interpretation, and thus there is no neutral stance from which they can gather objective knowledge about the world (Price \& Reus-Smit 1998), but they differ about how this interpretation should be done and what kinds of explanation it yields. The clearest division is between what Price \& Reus-Smit term modern and postmodern variants of constructivism. Postmodernist constructivists reject efforts to find a point from which to assess the validity of analytical and ethical knowledge claims. This stance makes it possible to deconstruct and critique the knowledge claims of others but makes it difficult to construct and evaluate new knowledge claims. For modern constructivists, on the other hand, acceptance that the world is always interpreted does not imply that all interpretations or explanations are equal; some types of explanation and evidence are more persuasive or logically and empirically plausible than others.

Modern constructivists may therefore be tackling different kinds of questions with broader notions of what constitutes causality than their rationalist or utilitarian colleagues, but practical investigation of these questions often leads them to similar methodological tasks. Like other social scientists, they must gather evidence, assess it, and arbitrate among explanations. Relevant and reliable evidence comes from many of the same sources widely used in other types of social analysis. Many of the world polity theorists in sociology, for example, use quantitative methods to describe overall characteristics of normative or cultural structures and plot change in these over time. Strang (1991), Boli (1987), and Ramirez et al (1997) have done this to track changes in the global distribution of sovereignty, citizenship rights, and women's rights. These analyses can provide correlative evidence about the timing and patterns of normative change but are less suited to understanding how and why change happens. To accomplish this, constructivists have used a variety of tools to capture intersubjective meanings, including discourse analysis, process tracing, genealogy, structured focused comparisons, interviews, participant observation, and content analysis.

In assessing this evidence and arbitrating among interpretations, constructivists use similiar criteria, as other researchers. They judge an interpretation of evidence by comparing it with alternative explanations. They search for evidence that would confirm alternatives and disconfirm the explanation being assessed. They ask if an explanation is supported by multiple streams of data (Putnam 1993). For example, they examine whether speech acts are consistent with other kinds of behavior in a case under investigation; whether qualitative findings are supported by or at least consistent with relevant statistical data; and whether actors explain and justify actions in similar ways in different settings (e.g. in private versus in public). Depending on the type of research, modern constructivists might also ask if the research can be duplicated. Good research need not be completely replicable (as participant-observer research may not be), but replication can enhance the plausibility of an interpretation. 
There is no single constructivist method or research design. Constructivism opens up a set of issues, and scholars choose the research tools and methods best suited to their particular question. In some cases, quantitative methods yield particular insight. In other cases, qualitative and interpretative methods are more appropriate. Many research projects have used a combination of these methods to illuminate different parts of a larger puzzle. In this sense, designing constructivist research is not fundamentally different from designing other kinds of research. Constructivists, like any other researchers, use the full array of available tools.

\section{ISSUES MOTIVATING RESEARCH IN INTERNATIONAL RELATIONS}

Unlike utilitarian (or rationalist) researchers, constructivists are not elaborating competing theories and engaging in wars among various "isms" (realism versus liberalism, for example). Rather, the modern constructivist research program seems to be developing in ways analogous to comparative politics. It focuses on issues, not on competing constructivist theories, and it aims at contingent generalizations. Surveying the empirical research, we see constructivists clustering around several prominent problems, engaging each other in debates about how to approach them and about what drives events in these areas, much as comparativists do. Our review of this research is organized around these issues.

\section{Global Norms versus Local Effects}

In a discipline that denied the independent causal effect of norms, rules, and social structures of meaning generally, the first task for constructivist empirical research in IR was obviously to establish that norms (and other social structures) matter. Much of the earlist constructivist work focused on this task. Katzenstein's edited volume, The Culture of National Security, was a conscious attempt to make this case to the most skeptical of audiences - the realists in security studies. Essays on weapons taboos, on military culture, on humanitarianism, and on identity politics all demonstrated how social structures of different kinds reshape actors' interests, self-understandings, and behavior (Katzenstein 1996a). Constructivists working on other political issues produced well-documented empirical studies showing the effectiveness of norms, which could not be easily reduced to interests of powerful states, in such diverse areas as foreign aid, opposition to slavery, piracy, trafficking in women, science policy, development, racism, and laws of war (Nadelman 1990; Finnemore 1993, 1996a; Crawford 1993; Lumsdaine 1993; Klotz 1995; Price 1995, 1997). The sociological institutionalists and world polity theorists, whose work began to be read in IR at this time, offered a similar causal focus. It showed how "world culture" reconfigured state policies, particularly the policies of developing states, in many different policy arenas (Meyer \& Hannan 1979, Bergesen 1980, Thomas et al 1987, Finnemore 1996b, Meyer et al 1997). All of 
these studies demonstrated that norms, culture, and other social structures have causal force and that these structures are not simple reflections of hegemonic state interests.

In an intellectual discourse where the causal status of social structures was widely questioned, simply establishing that these things matter was an important showing for constructivist scholars. However, this research, which focused on causality in only one direction-norms and social understandings influencing agents - was quickly questioned. Scholars were quick to notice that norms and social understandings often had different influences on different agents, and explaining these differences was soon identified as a crucial constructivist research task. Checkel's essays in the European Journal of International Relations (1997) and World Politics (1998) were prominent and early examples of this critique. Not only do different states react differently to the same international norms, he argued, but the mechanisms by which norms are internalized within states differ as well. Without understanding how these domestic processes worked, we could not understand the political effects of these global social structures. By bringing investigation of global norms back into domestic politics, Checkel and others have created an important point of intersection between international relations and comparative politics.

Following Checkel's critique, a variety of studies have investigated how international norms influence different actors (usually states) differently. A study of ten countries' reactions to international human rights norms showed how regime type, civil war, and the presence of domestic human rights organizations affect the degree to which states will comply with international human rights norms (Risse et al 1999). The authors proposed a generalized model of the process by which this happens. Checkel's own research (2001) on variations in compliance with European norms by Ukraine and Germany follows a similar pattern. Gurowitz (1999), in a study of the impact of refugee norms, argued that states with insecure international identities, such as Japan, respond more to international norms than countries with secure international identities, such as Germany.

The blind spots and biases of these two groups of constructivist researchers are predictable and complementary. One group is trying to show that global social structures exist and have powerful effects. These scholars tend to emphasize adherence with international norms or rules and downplay variations in compliance. The danger in this view comes when scholars forget that there is local variation in reaction to these norms and begin to treat international norms as a global "oobleck" that covers the planet and homogenizes us all (Seuss 1970). Similarly, these scholars sometimes overlook the fact that international norms have to come from somewhere and may not identify feedback effects from local agents onto global structures (Kaufman \& Pape 1999). World polity and world culture research in sociology often look dangerously biased in these ways to political scientists. The other group of scholars is interested precisely in these local variations in norm effects and tends to obscure or take for granted the other group's finding of the strong overall impact of ideational phenomena. The danger here is that scholars 
can become so concerned with detailing the variations in local reaction that they lose sight of large overall shifts in the global normative fabric. Disagreements between these groups flow from their different vantage points. They are not, as far as we can tell, disagreeing that social construction is going on and that it has large overall effects, nor even disagreeing about how it might happen.

\section{Ideas and Power}

In their efforts to establish independent causal force for norms and ideas, many constructivist studies have emphasized the ways in which ideas and norms run counter to or undermine conventional conceptions of strong state interests. Human rights norms, the preference of the weak, have been shown to triumph over strong actors and strong states; environmental norms prevail over powerful corporate business preferences (Wapner 1996, Keck \& Sikkink 1998, Risse et al 1999). However, another strand of constructivist scholarship has been much more skeptical about this autonomy of ideas from power. Work of "critical" constructivism has intellectual roots in critical social theory, including such figures as Anthony Giddens, Jurgen Habermas, and Michel Foucault. Although it shares the core features of constructivism identified above, critical constructivism adds a belief that constructions of reality reflect, enact, and reify relations of power. Critical constructivists believe that certain powerful groups play a privileged role in the process of social construction. The task of the critical scholar is both to unmask these ideational structures of domination and to facilitate the imagining of alternative worlds. Critical constructivists thus see a weaker autonomous role for ideas than do other constructivists because ideas are viewed as more tightly linked to relations of material power (Weldes et al 1999, Price \& Reus-Smit 1998).

Critical constructivists are increasingly engaged in rich empirical work. Their purpose is not to build or test new causal theory but to denaturalize dominant constructions, in part by revealing their connection to existing power relations. Weldes' work on the Cuban missile crisis, for example, argues that the crisis was a social construction forged by US officials in the process of reasserting its identity as a leader of the free world (Weldes 1996). Doty (1996) shows how the powerful western countries constructed civilizing discourses about the southern countries in order to justify violent counterinsurgency policies and economic exploitation. Weber (1999) uses gendered and sexual metaphors to explain the US obsession with relatively small perceived threats in the Caribbean and Central America, which she sees as strategies for recovering phallic power, lost in its encounter with Cuba.

An important contribution of critical IR theory has been to remind IR theorists that many of the categories we treat as natural are in fact products of past social construction processes, processes in which power is often deeply implicated.

\section{Identity and State Action}

One of the main contributions of constructivism is the notion that state identity fundamentally shapes state preferences and actions. Wendt $(1992,1994)$ and 
Katzenstein $(1996 a, b)$ helped put identity issues at the center of much constructivist theorizing. Constructivists agree that state identities were constructed within the social environment of international and domestic politics. They disagree, however, on the definitions of identity and the weight of international versus domestic environments in shaping state identities. Wendt's systemic constructivism places more emphasis on the impact of the international environment. For the authors in Katzenstein's edited volume (1996a), identity was mainly a domestic attribute arising from national ideologies of collective distinctiveness and purpose that in turn shaped states' perceptions of interest and thus state policy (Barnett 1996, Berger 1996, Risse-Kappen 1996).

The ongoing difficulty in identity research is that there is still no clear, agreedon definition of what we mean (and do not mean) by identity, how researchers can plausibly establish what state identities are, or what range of prominent identities may exist in international politics at any particular historical moment. Identity has become a catch-all term, helping to explain richly a wide variety of actions, but it does not yet permit us to suggest that states with particular types of identities will act in particular ways (Kowert \& Legro 1996). As long as identity remains unspecified, it will produce very particularistic explanations for state action and provide little hope of contingent generalizations about identity and world politics.

Wendt (1999) has moved modern constructivism along in addressing this problem. Wendt argues that identities are rooted in an actor's self-understandings (and are thus subjective) but also depend on whether that identity is recognized by other actors, which gives them an intersubjective quality. Thus, identities are constituted by the interaction of these internal and external ideas. This suggests that the number of possible identities is not infinite and the concept not idiosyncratic, since identity formation is always limited by the array of possible identities in the international system at any historical moment.

Wendt suggests that two kinds of identities are particularly important for international affairs: type identities and role identities. Type identities are social categories of states that share some characteristics, such as regime types or forms of state. States may have multiple type identities - a democratic state, a capitalist state, an Islamic state, a European state. International social structure is important here, because at any one time, certain type identities have more or less international legitimacy. For example, monarchical states are less legitimate today, and democratic and capitalist states are increasingly so. Role identities are the product of dyadic relationships among countries. States may be friends, rivals, or enemies. Role identities are uniquely social — they exist only in relation to others. Knowing about a state's perception of its identity (both type and role) should help us to understand how the state will act.

Much more work, both theoretical and empirical, is needed to clarify what are the range of possible type identities at any particular historical moment, how internal and external factors interact to produce actors with particular identities, and how, in turn, such identities affect state action. Work in comparative politics on ethnic identities may be useful for IR constructivist scholars working on identity. 
Most comparative scholars working on identity see it as socially constructed but argue that actors may strategically construct their identities from a more limited menu of type identities that are appropriate at a given historical moment (Laitin 1998, Fearon \& Laitin 2000). This menu also is socially constructed, and thus there are significant changes from one historical period to another. Yet, in each period, it is likely that this menu of possible type identities is limited.

\section{Mechanisms and Processes of Social Construction}

Another big research problem being tackled by constructivists is the identification of mechanisms and processes by which social construction occurs. Once it was established that norms and social structures matter, a next obvious step was to investigate how, exactly, they came to matter and how they came to exist at all. Work on this set of problems has highlighted a variety of possible mechanisms.

\section{NORM ENTREPRENEURS}

One broad swathe of research has focused on the purposive efforts of individuals and groups to change social understandings. People who dislike existing norms and rules in politics often band together and try to change them. A number of scholars have sought to understand how these groups operate and the conditions that might contribute to their success. These cases present attractive research puzzles because activists working for change often have few levers of conventional power relative to those controlling existing structures (often the state or corporations); to the extent that activists succeed, these situations are not easily explained by dominant utilitarian approaches, and they open space for constructivist alternatives.

Wapner (1996) shows that much of the important work of environmental activists happened outside of the arena of the state, where IR scholars traditionally focus. He provides extensive evidence of the transformative effects of civic interactions between private actors with transnational characteristics-in his case, multinational corporations and transnational activist groups. Much of what is important in world environmental politics, he argues, happens "beyond the state." Transnational civil society frames issues, helps set agendas, and mobilizes publics. States, in many instances, are only reacting to political changes fomented in an increasingly transnational civil society.

A complementary line of research has explored activism with particular emphasis on activists' work within, not beyond, states. Klotz (1995) and Thomas (2001) both emphasize the ways in which activists work with and within the bureaucracies of important states to achieve and consolidate new norms and social understandings. Klotz (1995) explores how antiapartheid activists steered the US and Commonwealth foreign policies in new directions, resulting in a very different normative climate for the apartheid regime in South Africa. Thomas (2001) 
similarly investigates the ways in which Helsinki movement activists were able to work through western governmental structures to press their human rights cases during the Cold War.

Once the importance of these nonstate actors was established, the next step for these researchers was to unpack the tools they used in their social construction work. Keck \& Sikkink (1998) and Risse et al (1999) analyzed the techniques used by activist groups, including strategic use of information, symbolic politics, leverage politics and accountability politics, issue framing, and shaming. Risse et al (1999) propose a five-stage model of how human rights violators become compliers.

\section{INTERNATIONAL ORGANIZATIONS AND LAW}

Other constructivists have focused on the role of international organizations in disseminating new international norms and models of political organization. Finnemore $(1993,1996 a, b)$ outlines the ways that international organizations "teach" states new norms of behavior. Similarly, Adler (1998) shows how the Organization for Security and Cooperation in Europe (OSCE) uses its legitimacy and perceived impartiality to carry out "seminar diplomacy" among its membersteaching them new values and new models of behavior. The mechanisms for social construction elaborated here draw heavily on Max Weber's work and on organization theory in sociology. Organizations are effective agents of social construction in part because the rational-legal authority they embody is widely viewed as legitimate and good. Further, the perceptions that these organizations are merely technical (not political) and that the social models they push are chosen because they are efficient and effective add to the power of these norms (Boli \& Thomas 1998, Barnett \& Finnemore 1999).

Other scholars have emphasized additional features of organizations that makes the effective engines of social construction. Ratner's (2000) study of the OSCE's High Commissioner for Minorities shows that his organizational role places the High Commissioner (HC) in a unique position to construct new international norms and rules. States often appeal to the HC for policy guidance, and he uses his position creatively to mediate conflicts by constructing new rules and new understandings of the existing rules or law acceptable to disputing parties. His legitimacy in his role, and the organization's authority in these matters, contributes to compliance with these new rules.

\section{EPISTEMIC COMMUNITIES}

Interest in the political effects of experts and specialized knowledge has existed in IR for decades. It coalesced into a research program on "epistemic communities" in the late 1980s and early 1990s (Haas 1992). Some of this work focused on 
knowledge effects in ways that were compatible with utilitarian approachesknowledge as a road map or focal point that helped utility-maximizing actors achieve their ends more effectively (Goldstein \& Keohane 1993). This is what Hasenclever et al (1997) call weak cognitivism and is similar to some of the "ideas" research in comparative politics, discussed below. But another group of epistemic communities researchers uses a broader understanding of knowledge and has contributed greatly to constructivist theorizing as well as the research program. Groups with specialized knowledge often have a common set of norms and world views; many scholars would argue that technical knowledge is never value neutral and always comes with an array of shared normative understandings that make it meaningful, therefore powerful, in social life. As they deploy their knowledge, these epistemic communities often disseminate new norms and understandings along with technical expertise. Consequently, they can act as powerful mechanisms of social construction. Adler's work (1992) on the ways in which arms control strategists in the United States learned game theory from the Rand Corporation in the Kennedy years and "taught" it and the entire deterrence framework to their Russian counterparts, making mutually assured destruction (MAD) seem rational, is one powerful example of social construction by such a group.

Expertise often resides inside formal organizations, so the two mechanisms can become intertwined in interesting ways. Adler's (1998) work on the "seminar diplomacy" of OSCE personnel explores aspects of this relationship, as does Finnemore's work (1993, 1996a) and Haas' earlier work on the Mediterranean clean-up endeavor (1989). Lawyers have been shown to do extensive social construction again, often in conjunction with international institutions that consolidate and formalize the new social facts lawyers create. Burley \& Mattli's (1993) analysis of the efforts of community lawyers to empower the then-new European Court of Justice illustrates the ways in which professional groups can translate their own shared understandings into formalized organizations and legal structures. Ratner's work (2000), discussed above, shares similar features.

\section{SPEECH, ARGUMENT, AND PERSUASION}

Other constructivists, following Habermas, have explored the role of argument as a mechanism of social construction. IR scholars have tended to treat speech either as "cheap talk," to be ignored, or as bargaining, to be folded into strategic interaction. However, speech can also persuade; it can change people's minds about what goals are valuable and about the roles they play (or should play) in social life. When speech has these effects, it is doing important social construction work, creating new understandings and new social facts that reconfigure politics. In one of the pioneering works of the field, Kratochwil (1989) examined the role of legal reasoning in persuasion and other social construction processes. More recently, German scholars have explored possibilities for Habermasian "communicative action" to change minds and world views (Risse 2000). Crawford follows 
a slightly different tack. She calls attention to the roles of both cognition and emotion in making arguments persuasive and shows how these are intertwined in deterrence, peace building, and other political projects (Crawford 1993, 2000).

\section{STRUCTURAL CONFIGURATION}

Most of the foregoing mechanisms for social construction explore the agentic side of this mutual constitution process; they identify new ways in which agents construct new social facts or new kinds of agents that might do the constructing. Bukovansky (2001) explores the structural side of this process in more detail and emphasizes the ways in which contradictions and complementarities in social structure create opportunities for agents. Using insights from sociologist Margaret Archer's work, she shows how an international political culture (the European Enlightenment) created a pattern of contradictions and complementarities that allowed some kinds of political legitimacy claims to succeed and not others. Reus-Smit (1999) has similarly explored the ways in which the structure of different "fundamental institutions" in international society shape the kinds of politics that are possible.

This list of mechanisms is not exhaustive. Constructivist researchers are identifying more mechanisms of social construction all the time. Further, these mechanisms often interact or even presuppose each other. For example, Habermasian persuasion presupposes a degree of affect (empathy) among participants. International organizations are almost always staffed by people with specialized knowledge who are involved in epistemic communities, creating interactions between bureaucracies and knowledge bases. Contradictions and complementarities cannot create new social structures by themselves; agents must react to these structures, using whatever means are at their disposal, to effect change. We suspect that an exploration of these interactive effects will be important in future constructive empirical research.

\section{A Bias Toward Progressive Norms?}

One consistent complaint about constructivist research has been its research focus on norms most of us would consider "good," such as human rights, protecting the environment, and promoting democracy. Constructivists have been quick to point out that there is no necessary reason for this orientation. To some extent, it is an artifact of the dominant approaches with which constructivism engaged in its early years. Neorealist and neoliberal theories that flowed from economic approaches to social analysis tended to understand interests consistently as selfinterest; other-regarding behavior was an anomaly to be explained. Consequently, social construction projects that were not obviously self-interested (e.g. promoting human rights for people far away or saving whales and dolphins) were difficult for dominant theories to explain and opened space for a constructivist alternative. 
The bias toward "nice" norms has persisted, however, even after constructivism established itself as a legitimate analytic approach in IR. Constructivists in IR have tended not to investigate the construction of xenophobic and violent nationalisms, for example, and the focus on social structures most of us admire has continued. Research has begun, however, on negative effects of these well-intentioned social construction projects. For example, authors in a Carnegie-funded project on democratization efforts in the former Soviet Union (Mendelson \& Glenn 2000) show how efforts to transform social facts in the former Soviet Union actually imperil human rights by empowering activists but then not protecting them, and make societies more corrupt by creating new conflicts between international normative demands and local social contexts. Similarly, Barnett \& Finnemore (1999) have begun researching the "pathologies" of international organizations, which often act as agents of social construction, and show how they can become captives of their own rules and procedures in ways that make them repressive, ineffective, or even counterproductive.

\section{CONSTRUCTIVIST ANALYSIS IN COMPARATIVE POLITICS}

For a number of reasons, it is difficult to relate debates in comparative politics to the constructivist debates in IR. First, comparativists rarely use the term constructivism to refer to their own work, and when they do, they often mean something different from constructivism in IR (Fearon \& Laitin 2000). Comparativists have tended to eschew the paradigm battle of the "isms" that has dominated IR, focusing instead on mid-level theoretical propositions for specific issue areas. Research in comparative politics tends to be driven by efforts to explain puzzles or questions rather than by the need to test a particular theoretical model. Scholars of comparative politics do not feel as compelled to maintain a consistent theoretical identity or to ensure that their work furthers a particular "ism" in the paradigm trench wars, and it is not at all unusual for a comparative scholar to work on different problems using different theoretical approaches (see, for example, the work of O'Donnell or Laitin). Second, the ideational concerns of the two subfields are on different levels of analysis. Cultural or ideological approaches were never absent from comparative politics, as they were absent from IR in the 1970s and 1980s, but these approaches focused on cultural and ideological forces in a particular country or region. Comparativists are often suspicious of, or less attentive to, arguments about the influence of international ideational and normative factors on domestic politics. Thus, they may resist the basic tenet of constructivism in IR that international-level ideational structures exercise a powerful force in the world creating similar global effects in many countries. Finally, comparativists have not had the same debates over method as IR scholars. Although comparativists have strived for conceptual clarity, refined comparative methods for case selection, and developed diverse and 
rigorous field research methods, many never embraced a strongly positivist model of social science. Many rely extensively on fieldwork and interpretive methods, which sit uneasily with the stricter positivist dictates of nonconstructivist IR.

The recent heated debate in comparative politics has been framed not as rationalism vs constructivism, as in IR, but as rational choice vs area studies. Sometimes the rational choice vs area studies division parallels the rationalism vs constructivism debate in IR, but often it does not. Issues of culture, language, and ideology have been present in some rational choice approaches to comparative politics (Laitin 1986, 1998), whereas many area studies scholars stress economic factors more than ideological or cultural ones. Other aspects of comparative politics scholarship display similar eclecticism. Two prominent "constructivist" critiques of comparative method were not written by comparative politics scholars at all but by a political theorist (McIntyre 1972) and an economist (Hirschman 1970). Other classic constructivist works that sometimes appear on comparative syllabi are likewise not by comparativists (Said 1979, Geertz 1980, Escobar 1984, Shapiro 1988).

When we look for constructivists in comparative politics, we find instead more eclectic scholars who at times make compelling arguments about discourses, language, ideas, culture, or knowledge relevant to specific thematic areas. Most of the comparative scholars who work on these issues are what Hasenclever et al (1997) would call weak cognitivists - although they focus on the independent role of ideas and knowledge, they often see their theories as complementing rather than supplanting interest-based theories. Below, we briefly explore four areas of comparative politics where such weak cognitivist arguments have been prevalent: the ideas literature, especially its treatment of the role of ideas in economic policy making; the political culture literature; the debates over the rise and role of social movements; and the literature on identities, especially national and ethnic identities.

\section{Ideas and Political Change}

Perhaps the most developed of these cognitivist literatures has been the ideas literature, used especially in the subfield of comparative political economy to explain the influence of economic ideas on economic policy making (Hall 1989, 1993, 1997; Sikkink 1991; Jacobson 1995; Blyth 1997; Berman 1998, 2001; McNamara 1998). The ideas literature echoes the first central tenet of constructivism on the importance of ideas and asks three main questions (Berman 2001, Sikkink 1991): (a) How do new ideas emerge and rise to prominence? (b) How do ideas become institutionalized and take on a life of their own? (c) How, why, and when do ideas matter in any particular circumstance? In answering the first question, this literature explicitly contests the common explanation in comparative politics that new ideas are imposed by those with political, military, or economic power. It stresses instead processes of learning in situations characterized by complexity, failure, anomaly, and new information. Heclo sums up the essence of such an approach: "Governments not only power. . they also puzzle" (1974:305). 
Learning approaches understand humans as engaged in reasoning and processing new information from the environment in an attempt to make sense of their world. The units of analysis in such work may be the individual, the community of individuals sharing common ideas, or the institutions in which ideas become embodied. The ideas literature is interested in the processes by which ideas initially held by a small number of individuals (such as a small school of economists) become widely held (intersubjective). Some of the ideas literature also stresses the third central tenet of constructivism: The interests of actors are constructed by these shared ideas rather than given by nature (Hall 1989, Sikkink 1991).

Comparative authors writing about ideas are in dialogue with IR literatures, but they tend to cite the "weak cognitivist" literature in IR, such as Goldstein \& Keohane (1993) or Haas's (1992) work on epistemic communities, rather than the constructivist writers discussed above. The comparative literature on ideas has more in common with this IR literature; both emphasize the role of ideas in facilitating action in situations of complexity or providing focal points around which political coalitions can form (Goldstein \& Keohane 1993). When they explain why some ideas win out over others, these literatures tend to emphasize neither the constitutive power of ideas nor an idea's intrinsic force, but rather its ability to clarify uncertainty or reconcile the interests of elites (Jacobson 1995). As a consequence, the ideas literature has been criticized by scholars who argue that it does not offer an alternative to the dominant rationalist perspective, but only ad hoc modifications of it (Blyth 1997, Laffey \& Weldes 1997).

Authors who use an ideas approach have pointed out that new ideas often emerge in response to dramatic policy shocks, failures, or crises, where past policies have failed to resolve problems, leading to a search for new conceptions on which to base new policies (Odell 1982, Kowert \& Legro 1996). This relationship between crisis and failure and the adoption of new ideas has been found in a number of different countries and time periods. The two types of crisis or failure most often mentioned are major depressions and war. But a failure argument alone is insufficient. Failure may explain why old ideas lose influence, but they do not explain the content of new models that are adopted. McNamara (1998) explains the adoption of monetary policies in the European Union based on three factors: policy failure, policy paradigm innovation, and policy emulation. In thinking about why people adopt new ideas, a useful supplement to the simple notions of failure or success is Hall's (1989) notion of persuasiveness. What makes an idea persuasive is the way the idea relates to the economic and political problems of the day. Both success and failure are interpreted in terms of what are perceived as the most pressing problems facing a country at a particular time.

Another explanation for the influence of new ideas focuses on a Kuhnian argument about the accumulation of anomalies-i.e. outcomes that do not fit the expectations induced by the existing paradigm. Rather than dramatic failure or crises, the anomaly argument suggests that it is the accumulation of small 
discrepancies that cannot be explained with the old model that eventually leads to the adoption of new ideas (Hall 1993, Sikkink 1997).

Comparativists have also pointed out that the strength and continuity of new ideas often depends on the degree to which they become embodied in institutions, and an important part of the ideas literature explores how ideas become institutionalized and what difference it makes. The ideas that are successfully implemented and consolidated are those that have been instilled within an institutional home, where a team of like-minded people transform their individual ideas into institutional purpose (Adler 1987, Hall 1997, Berman 1998, McNamara 1998, Sikkink 1991). Many of these institutions are state institutions, but institutions outside the state, including universities, labor unions, and political parties (Berman 1998), have also played important roles in the transmission and continuity of policy ideas. Differences in how new ideas fit existing institutions can help explain divergent policy responses (Skocpol \& Weir 1985, Hall 1993). Finally, in order to be internalized, new ideas need not only to be institutionalized, but also to fit or be congruent with historically formed ideologies or the structure of political discourse of a nation (Hall 1989). This line of argument has obvious complementarities with the work of IR constructivists on the role of organizations in social construction.

A related literature in comparative politics in the "learning" literature, which has focused in particular on political learning and redemocratization. This literature draws more explicity on the social psychological studies to argue that learning and the internalization of new attitudes and behavior are an important source of political change. Like the ideas literature, it argues that crisis or trauma, such as those caused by intense repression, can lead actors to reject their previous attitudes supporting authoritarianism and develop attitudes supporting democracy. The mechanisms that lead to learning include interaction (with domestic and international actors), comparison (with prior national experiences and with other countries' experiences), reflection (including internal debates and self-criticism), and personnel change (Bermeo 1992, McCoy 2000).

\section{Political Culture}

The concept of political culture has been a staple of the comparative politics literature since the 1960s (Turner 1995). One of the two main variants of modernization theory offered a strong cultural account of underdevelopment, arguing that many less developed countries lacked the elements of political culture required for democracy to flourish (Lipset 1967, Silvert 1967, Wiarda 1982). It stressed (without using the words) that culture constructed the individual and that cultural elements created the possibility (or the impossibility) for particular types of political institutions to flourish or even survive (compare Thomas et al 1987 for a theoretically similar argument in an explicitly constructivist mode). This version of modernization theory was criticized, both for ethnocentrism and for its 
inability to explain the diversity of development paths followed by the West and the less developed world. It further implied that individuals are virtual prisoners of their culture. This powerful critique of an all-encompassing cultural account of development may have had the side effect of discrediting strong cultural accounts in comparative politics.

Some would claim that the political culture theorists in comparative politics are doing something quite different from constructivists in IR, but this literature clearly fits the two core tenets of constructivism better than the ideas literature. Here culture is seen as the primary explanation for change, it is clearly intersubjective, and it has real constitutive force. Wildavsky (1989), for example, argues that "culture constitutes one's political self." IR scholars, in their enthusiasm for concepts of culture and socialization, could find a cautionary tale in the political culture literature-both the controversies it generated and the difficulties it encountered with definitions, operationalization, and research design.

More recent arguments about political culture in comparative politics include work by Inglehart (1988, 1990, 1997), Laitin (1998), and Putnam (1993). All offer powerful arguments about the importance of political culture, but in each case, culture is ultimately an intervening variable rather than the primary explanation. Inglehart (1990) argued that a particular stage of development in advanced industrial countries leads to a "culture shift" to a set of "post-materialist" values, which in turn explains key aspects of politics. More recently (Inglehart 1997), he has updated and expanded this argument, using data from the World Values Surveys, to claim that industrialization and economic development throughout the world are leading to cultural change and political change. To Inglehart, values play the crucial intervening variable role but are not constitutive.

The recent political culture arguments do not stress the intrinsic power of particular cultural beliefs to explain their influence and wide acceptance. Inglehart (1997) argues that certain cultural characteristics survive and spread because they serve functional purposes in particular settings. Post-materialist values would not appear in poor contries because they would undermine development (Inglehart 1997; also see Berman 2001). Anderson's (1990) critique of Inglehart, using data from peasants in Costa Rica and Nicaragua, argues that culture has more of an independent effect, claiming that post-materialist values are present in societies that have not attained high levels of development. Putnam sees social capital, and a particular culture of trust, as the result of centuries of association (1993). Once again, the independent variable is association - people joining groups-which leads to social capital and a culture of trust, which in turn contributes to making democracy work and to economic development.

\section{Social Movement Theory}

Another subfield of comparative politics that has developed a debate about what we could call constructivism is social movement theory. The debate in social 
movement theory between the resources mobilization school, political opportunity structures approaches, and the new social movement perspective reflected some aspects of the debate between rational choice and constructivist approaches to comparative politics. Resource mobilization theories, originally dominant in the United States, stressed strategy, organization, rationality, expectation, and interests. Political opportunity structure approaches explored social movements operating within a structure of constraints and opportunities that made their survival and success more or less likely. The new social movement approach, dominant in Europe and Latin America, emphasized that collective identities were as essential for understanding the emergence and actions of social movements (Escobar \& Alvarez 1992). This debate was summed up as "strategy vs. identity" (Cohen 1985) and came to be understood as a debate over whether social movement actors were mainly driven by a need to express their identity or mainly driven by more strategic concerns of where and when they could win.

For a few years, the social movement literature was characterized by a clash of paradigms, as proponents of resource mobilization, political opportunity structure, or new social movements approaches struggled for dominance. But like other debates in comparative politics, the clarity of this debate (strategy versus identity) did not last long, and the modern social movement scholar tends to be theoretically eclectic. Identity proponents recognized that they may have prematurely celebrated new identities while tending to neglect the constraints that movements faced (Escobar \& Alvarez 1992). Strategy proponents realized that they were often puzzled by the emergence of a wide range of new identity-based movements. Many scholars argued for theoretical synthesis and cross-pollination, and such efforts are well under way. European, US, and Latin American scholars are currently integrating propositions from various models to determine not which model is superior, but rather which concepts are useful for understanding particular aspects and stages of social movements (Escobar \& Alvarez 1992, Starn 1992, McAdam et al 1996, Klandermans 1997).

Whereas IR theorists talk of norms, social movement theorists tend to talk of collective or shared beliefs. Social movement theorists have long been preoccupied with the process of meaning creation, and in the 1990s, "the social construction of meaning [became] a central part of social movement theory" (Klandermans 1997). Movements help to create and recreate meanings through "framing" or "the conscious strategic efforts by groups of people to fashion shared understandings of the world and of themselves that legitimate and motivate collective action" (McAdam et al 1996:6) Social movements turn new ideas into frames that define the issues at stake and the appropriate strategies for action. Framing occurs not only through what movements say but also through what they do-through their choices of tactics and the connections between their actions and their rhetoric (McAdam et al 1996). Movements then use these frames to attempt the "mobilization of consensus," that is, communication intended to persuade others to take their side (Klandermans 1997). Because of the proliferation of transnational social movements, this is one area where there has been some fruitful theoretical 
exchange between IR scholars and comparativists [Tarrow 2001 (Chapter 1 of this volume), Smith et al 1997].

\section{Identity and Ethnicity}

Anderson's Imagined Communities (1983) is a premier example of constructivist theorizing by a comparativist. Anderson argues that all communities larger than primordial villages are imagined, and thus are to be distinguished "not by their falsity or genuineness, but by the style in which they are imagined." For Anderson, the rise of national identity is closely linked to the expansion of capitalism, the rise of printing, and the use of vernacular languages, but once the community is imagined, it takes on a powerful life of its own.

Others, working in the related area of the ethnic identities, also point to the constructed and imagined nature of ethnic identity. But once again, this literature takes a different slant from the debates in IR between rationalists and constructivists. Indeed, the main debate over identity in comparative politics is not whether identity matters (this is the IR debate) but whether identity is inherited like skin color (primordialism) or is, in Laitin's (1998) words, constructed like an art object. In this schema, Geertz, whom most IR theorists would consider a constructivist, is sometimes classified as a primordialist, because he assumes that culture and symbols are powerful and unchanging influences on life. Laitin, who is identified with rational choice theory, calls himself a constructivist because he argues that identities are socially constructed. These scholars argue that it is fully consistent to believe that identities are socially constructed but that actors may make rational choices about how to construct their identities.

In Politics, Language, and Thought: The Somali Experience (1977), Laitin underscored the power of language to construct political identities and action. A change in the official language led Somalis to change the ways they thought and acted politically. In Hegemony and Culture (1986), however, Laitin argued that religious change among the Yoruba, contrary to what Weber or Geertz might lead us to expect, did not lead to adjustments in social and political behavior. Laitin claimed that both religion and tribe were potential identities that could be the basis for collective action, and he explored the conditions under which a particular cultural divide in a society is seen as deeper or more important for collective action than another. He joined together an interpretive account of culture, a rational actor approach, and a "neo-positivist" method aimed at providing both contextual understanding and the possibility for falsification. Identity in Formation: The Russian Speaking Populations in the Near Abroad (Laitin 1998) continues this project of uniting constructivism with rational choice. According to Laitin (1998:12), "construction and choice, rather than blood and inheritance, is now the standard line about identities." This blurs the distinctions used in IR, where the distinction is construction versus choice, not construction and choice versus blood and inheritance. For comparativists in this tradition, if 
identities are constructed, this implies that actors have choices about identities and might use rational calculations in constructing their identities. Identities, in this view, have a dual nature: They appear natural to members of groups even as individuals engage in projects of identity construction (Laitin 1998). This literature argues that actors construct or choose these identities from a menu of existing choices. The menu is historically and culturally constructed, but individuals choose rationally from the items that are on the menu at any given point.

\section{POSSIBILITIES FOR FRUITFUL CROSS-FERTILIZATION}

Although there has not yet been extensive contact between comparativistis and IR scholars, there are a number of avenues for promising cross-fertilization. Comparativists have long pursued building mid-level theory similar to what Price \& Reus-Smit (1998) call small-t theoretical generalizations. Since these generalizations are now increasingly the object of much modern constructivist theorizing, there may be less mismatch between the macro theorizing in IR and mid-level theory in comparative politics.

Second, the processes of globalization have made even the most passionate country specialists aware of the increasing influence of international factors, both material and ideational, on domestic politics around the globe. Comparativists are becoming increasingly attentive to the interpenetration of international affairs and domestic politics (Putnam 1988, Whitehead 1996). For example, social movement theorists now realize that they need to be attentive not only to domestic social movements but also to transnational social movements and to the linkages between domestic and transnational movements. Social movement theorists are increasingly aware that social movements operate in both a domestic and an international environment; they speak of "multi-layered" opportunity structure including a "supranational" layer, or a "multi-level polity," or highlight how international pressures influence domestic opportunity structures (McAdams et al 1996, Klandermans 1997, Tarrow 2001). One area for future fruitful exchange between ideational scholars of comparative politics and IR is to conceptualize theories of how domestic and transnational political opportunity structures might interact with one other in a continuous manner and what characteristic patterns would result.

At the same time, IR scholars with comparative training have made compelling arguments that a better understanding of domestic political and ideational structures is a necessary precondition to furthering constructivist theorizing about when and why international norms and cultures influence specific domestic settings (Risse-Kappen 1995; Katzenstein 1996a,b; Checkel 1997, 1998). To further this agenda, they will increasingly engage in comparative politics research and in dialogues with comparative scholars. 


\section{Visit the Annual Reviews home page at www.AnnualReviews.org}

\section{LITERATURE CITED}

Adler E. 1987. The Power of Ideology: The Quest for Technological Autonomy in Argentina and Brazil. Berkeley: Univ. Calif. Press

Adler E. 1992. The emergence of cooperation: national epistemic communities and the international evolution of the idea of nuclear arms control. Int. Org. 46:101-45

Adler E. 1997. Seizing the middle ground: constructivism in world politics. Eur. J. Int. Relat. 3:319-63

Adler E. 1998. Seeds of peaceful change: the OSCE's security community-building model. In Security Communities, ed. E Adler, M Barnett, pp. 119-59. New York: Cambridge Univ. Press

Adler E, Barnett M. 1998. Security Communities. Cambridge, UK: Cambridge Univ. Press

Anderson B. 1983. Imagined Communities: Reflections on the Origins and Spread of $\mathrm{Na}$ tionalism. London: Verso

Anderson L. 1990. Post-materialism from a peasant perspective: political motivation in Costa Rica and Nicaragua. Comp. Polit. 23:80-113

Barnett MN. 1996. Identity and alliances in the Middle East. See Katzenstein 1996a, pp. 400-47

Barnett MN. 1998. Dialogues in Arab Politics. New York: Columbia Univ. Press

Barnett MN, Finnemore M. 1999. The politics, power, and pathologies of international organizations. Int. Org. 53:699732

Berger TU. 1996. Norms, identity and national security in Germany and Japan. See Katzenstein 1996a, pp. 317-56

Bergesen A, ed. 1980. Studies of the Modern World-System New York: Academic

Berman S. 1998. The Social Democratic Moment: Ideas and Politics in the Making of Interwar Europe. Cambridge, UK: Harvard Univ. Press
Berman S. 2001. Ideas, norms and culture in political analysis. Comp. Polit. In press

Bermeo N. 1992. Democracy and the lessons of dictatorship. Comp. Polit. 24:273-91

Blyth M. 1997. Any more bright ideas? Comp. Polit. 29:229-50

Boli J. 1987. Human rights or state expansion? Cross-national definitions of constitutional rights, 1870-1970. In Institutional Structure: Constituting State, Society and the Individual, ed. G Thomas, JW Meyer, FO Ramirez, J Boli, pp. 133-49. Newbury Park, CA: Sage

Boli J, Thomas GM, eds. 1998. Constructing World Culture: International Nongovernmental Organizations Since 1875. Stanford: Stanford Univ. Press

Bukovansky M. 2001. Ideas and Power Politics: The American and French Revolutions in International Political Culture. Princeton, NJ: Princeton Univ. Press

Burley AM, Mattli W. 1993. Europe before the court: a political theory of legal integration. Int. Org. 47:41-76

Checkel JT. 1997. International norms and domestic politics: bridging the rationalistconstructivist divide. Eur. J. Int. Relat. 3:473-95

Checkel JT. 1998. The constructivist turn in international relations theory. World Polit. 50:324-48

Checkel JT. 2001. Why comply? Social learning and European identity change. Int. Org. forthcoming

Cohen J. 1985. Strategy or identity: new theoretical paradigms and contemporary social movements. Soc. Res. 52:663-716

Crawford N. 1993. Decolonization as an international norm: the evolution of practices, arguments, and beliefs. In Emerging Norms of Justified Intervention, ed. L Reed, C Kaysen, pp. 37-61. Cambridge, MA: Am. Acad. Arts Sci. 
Crawford N. 2000. The passion of world politics. Int. Sec. 24:116-56

Doty RL. 1996. Imperial Encounters. Minneapolis: Univ. Minn. Press

Escobar A. 1984. Discourse and power in development: Michel Foucault and the relevance of his work to the Third World. Alternatives 10:377-400

Escobar A, Alvarez S, eds. 1992. The Making of Social Movements in Latin America: Identity, Strategy, and Democracy. Boulder, CO: Westview

Fearon J, Laitin D. 2000. Violence and the social construction of ethnic identity. Int. Org. 54:845-77

Ferguson J. 1990. The Anti-Politics Machine: Development, Depolitization, and Bureaucratic Power in Lesotho. New York: Cambridge Univ. Press

Finnemore M. 1993. International organizations as teachers of norms: the United Nations educational, scientific, and cultural organization and science policy. Int. Org. 47:565-97

Finnemore M. 1996a. National Interests in International Society. Ithaca, NY: Cornell Univ. Press

Finnemore M. 1996b. Norms, culture, and world politics: insights from sociology's institutionalism. Int. Org. 50:325-47

Geertz C. 1980. Negara: The Theater-State in 19th Century Bali. Princeton, NJ: Princeton Univ. Press

Goldstein J, Keohane RO, eds. 1993. Ideas and Foreign Policy: Beliefs, Institutions and Political Change. Ithaca, NY: Cornell Univ. Press

Gurowitz A. 1999. Mobilizing international noms: domestic actors, immigrants, and the Japanese state. World Polit. 51:413-45

Haas P. 1989. Do regimes matter? Epistemic communities and Mediterranean pollution control. Int. Org. 43:377-405

Haas P, ed. 1992. Knowledge, power, and international policy coordination. Int. Org. 46 (spec. issue)

Hall PA. 1989. Conclusion: the politics of Key- nesian ideas. In The Political Power of Economic Ideas, ed. P Hall, pp. 351-91. Princeton, NJ: Princeton Univ. Press

Hall PA. 1993. Policy paradigms, social learning, and the state. Com. Polit. 25:275-96

Hall PA. 1997. The role of interests, institutions, and ideas in the comparative political economy of the industrialized nations. In Comparative Politics: Rationality, Culture, and Structure, ed. MLichbach, AZuckerman, pp. 174-207 New York: Cambridge Univ. Press Hasenclever A, Mayer P, Rittberger V. 1997. Theories of International Regimes. Cambridge, UK: Cambridge Univ. Press

Heclo H. 1974. Modern Social Policies in Britain and Sweden. New Haven, CT: Yale Univ. Press

Hirschman AO. 1970. The search for paradigms as a hindrance to understanding. World Polit. 22:329-43

Inglehart R. 1988. The renaissance of political culture. Am. Polit. Sci. Rev. 82:1203-30

Inglehart R. 1990. Culture Shift in Advanced Industrial Society. Princeton, NJ: Princeton Univ. Press

Inglehart R. 1997. Modernization and Postmodernization: Cultural, Economic, and Political Change in 43 Societies. Princeton, NJ: Princeton Univ. Press

Jacobson JK. 1995. Much ado about ideas: the cognitive factor in economic policy. World Polit. 47:283-310

Katzenstein PJ, ed. 1996a. The Culture of $\mathrm{Na}$ tional Security Norms and Identity in World Politics. New York: Columbia Univ. Press

Katzenstein PJ. 1996b. Cultural Norms and National Security Police and Military in Postwar Japan. Ithaca, NY: Cornell Univ. Press

Katzenstein PJ, Keohane RO, Krasner SD, eds. 1999. Exploration and Contestation in the Study of World Politics. Cambridge, MA: MIT Press

Kaufmann C, Pape R. 1999. Explaining costly international moral action: Britain's sixtyyear campaign against the Atlantic slave trade. Int. Org. 53:631-68

Keck M, Sikkink K. 1998. Activists Beyond 
Borders: Advocacy Networks in International Politics. Ithaca, NY: Cornell Univ. Press

Keeley J. 1990. Toward a Foucauldian analysis of international regimes. Int. Org. 44:83-105

Keohane RO. 1988. International institutions: two approaches. Int. Stud. Q. 32:379-96

Klandermans B. 1997. The Social Psychology of Protest. Oxford, UK: Blackwell

Klotz A. 1995. Norms in International Relations: The Struggle against Apartheid. Ithaca, NY: Cornell Univ. Press

Kowert P, Legro J. 1996. Norms, identity, and their limits: a theoretical reprise. See Katzenstein 1996a, pp. 451-97

Kratochwil F. 1989. Rules, Norms, and Decisions: On the Conditions of Practical and Legal Reasoning in International Relations and Domestic Affairs. Cambridge, UK: Cambridge Univ. Press

Laffey M, Weldes J. 1997. Beyond belief: ideas and symbolic technologies in the study of international relations. Eur. J. Int. Relat. 3:193237

Latin D. 1977. Politics, Language and Thought: The Somali Experience. Chicago: Univ. Chicago Press

Laitin D. 1986. Hegemony and Culture: Politics and Religious Change among the Yoruba. Chicago: Chicago Univ. Press

Laitin D. 1998. Identity in Formation: The Russian Speaking Populations of the Near Abroad. Ithaca, NY: Cornell Univ. Press

Lipset S. 1967. Values, education, and entrepreneurship. In Elites in Latin America, ed. S Lipset, A Solari, pp. 3-60. New York: Oxford Univ. Press

Lumsdaine D. 1993. Moral Vision: The Foreign Aid Regime 1949-1989. Princeton, NJ: Princeton Univ. Press

McAdam D, McCarthy JD, Zald MN, eds. 1996. Comparative Perspectives on Social Movements: Political Opportunities, Mobilizing Structures, and Cultural Framings. New York: Cambridge Univ. Press

McCoy J, ed. 2000. Political Learning and Redemocratization in Latin America: Do Politi- cians Learn from Political Crises? Miami, FL: North-South Ctr.

McIntyre A. 1972. Is a science of comparative politics possible? In Philosophy, Politics, and Society, ed. P Laslett, WG Runciman, Q Skinner, pp. 8-26. Oxford, UK: Blackwell McNamara K. 1998. The Currency of Ideas: Monetary Politics in the European Union. Ithaca, NY: Cornell Univ. Press

Mendelson S, Glenn J. 2000. Democracy assistance and NGO strategies in post-communist societies. Work. Pap. No. 8, Carnegie Endowment for International Peace, Feb. 2000

Meyer JW, Boli J, Thomas GM. 1987. Ontology and rationalization in the Western cultural account. In Institutional Structure: Constituting State, Society, and the Individual, ed. G Thomas, JW Meyer, FO Ramirez, J Boli, pp. 12-37. Newbury Park, CA: Sage

Meyer JW, Boli J, Thomas GM, Ramirez FO. 1997. World society and the nation state. Amer. J. Sociol. 103:144-81

Meyer JW, Hannan MT, eds. 1979. National Development and the World-System: Educational, Economic and Political Change, 1950-1970. Chicago: Univ. Chicago Press

Meyer JW, Ramirez FO, Soysal Y. 1992. World expansion of mass education, 1870-1980. Soc. Ed. 65:128-49

Nadelman E. 1990. Global prohibition regimes: the evolution of norms in international society. Int. Org. 40:479-526

Odell J. 1982. U.S. International Monetary Policy: Markets, Power, and Ideas as Sources of Change. Princeton, NJ: Princeton Univ. Press

Price R. 1995. A genealogy of the chemical weapons taboo. Int. Org. 49:73-104

Price R. 1997. The Chemical Weapons Taboo. Ithaca, NY: Cornell Univ. Press

Price R, Reus-Smit C. 1998. Dangerous liaisons? Critical international relations theory and constructivism. Eur. J. Int. Relat. 4:25994

Putnam R. 1988. Diplomacy and domestic politics: the logic of two-level games. Int. Org. 42:427-60

Putnam R. 1993. Making Democracy Work: 
Civil Traditions in Modern Italy. Princeton, NJ: Princeton Univ. Press

Ramirez FO, Soysal Y, Shanahan S. 1997. The changing logic of political citizenship: crossnational acquisition of women's suffrage rights, 1890-1990. Am. Sociol. Rev. 62:735-45

Ratner SR. 2000. Does international law matter in preventing ethnic conflict? J. Int. Law Polit. 32:591-698

Reus-Smit C. 1999. The Moral Purpose of the State: Culture, Social Identity, and Institutional Rationality in International Relations. Princeton, NJ: Princeton Univ. Press

Risse T. 2000. "Let's argue!": Communicative action in world politics. Int. Org. 54:1-40

Risse T, Ropp S, Sikkink K, eds. 1999. The Power of Human Rights: International Norms and Domestic Change. Cambridge, UK: Cambridge Univ. Press

Risse-Kappen T, ed. 1995. Bringing Transnational Relations Back In: Non-State Actors, Domestic Structures, and International Institutions. New York: Cambridge Univ. Press

Risse-Kappen T. 1996. Collective identity in a democratic community: the case of NATO. See Katzenstein 1996a, pp. 357-99

Ruggie JG. 1998. What makes the world hang together? Neo-utilitarianism and the social constructivist challenge. Int. Org. 52:855-87

Said E. 1979. Orientalism. New York: Vintage

Searle J. 1995. The Construction of Social Reality. New York: Free

Seuss D. 1970. Bartholomew and the Oobleck. New York: Random House

Shapiro MJ. 1988. The Politics of Representation. Madison: Univ. Wisc. Press

Sikkink K. 1991. Ideas and Institutions: Developmentalism in Brazil and Argentina. Ithaca, NY: Cornell Univ. Press

Sikkink K. 1997. Development ideas in Latin America: paradigm shift and and the Economic Commission for Latin America. In International Development and the Social Sciences: Essays on the History and Politics of Knowledge, ed. F Cooper, R Packard, pp. 228-56. Berkeley: Univ. Calif. Press
Silvert K. 1967. The politics of social and economic change in Latin America. Sociol. Rev. Mon. 11:47-58

Skocpol T, Weir M. 1985. State structures and the possibilities for Keynesian responses to the depression in Sweden, Britain, and the United States. In Bringing the State Back In, ed. PEvans, D Rueschemeyer, T Skocpol, pp. 107-63. Cambridge, UK: Cambridge Univ. Press

Smith J, Chatfield C, Pagnucco R, eds. 1997. Transnational Social Movements and Global Politics. Syracuse, NY: Syracuse Univ. Press Starn O. 1992. "I dreamed of foxes and hawks": reflections on peasant protest, new social movements, and the Rondas Campesinas of Northern Peru. See Escobar \& Alvarez 1992, pp. 89-111

Strang D. 1991. Anomaly and commonplace in European political expansion: realist and institutionalist accounts. Int. Org. 45:143-62

Tarrow S. 2001. Transnational politics: contention and institutions in international politics. Annu. Rev. Polit. Sci. 4:1-20

Thomas D. 2001. The Helsinki Effect: International Norms, Human Rights, and the Demise of Communism. Princeton, NJ: Princeton Univ. Press

Thomas GM, Meyer JW, Ramirez FO, Boli J, eds. 1987. Institutional Structure: Constituting State, Society and the Individual. Newbury Park, CA: Sage

Turner FC. 1995. Reassessing political culture. In Latin America in Comparative Perspective, ed. PH Smith, pp. 195-224. Boulder, CO: Westview

Wapner P. 1996. Environmental Activism and World Civic Culture. Albany: State Univ. NY Press

Weber C. 1999. Faking It: U. S. Hegemony in a "Post-Phallic" Era. Minneapolis: Univ. Minn. Press

Weldes J. 1996. Constructing National Interests: The United States and the Cuban Missile Crisis. Minneapolis: Univ. Minn. Press

Weldes J, Laffey M, Gusterson H, eds. 1999. Cultures of Insecurity: States, Communities, 
and the Production of Danger. Minneapolis: Univ. Minn. Press

Wendt A. 1987. The agent-structure problem in international relations theory. Int. Org. 41:335-70

Wendt A. 1992. Anarchy is what states make of it. Int. Org. 46:391-425

Wendt A. 1994. Collective identity formation and the international state. Am. Polit. Sci. Rev. 88:384-96

Wendt A. 1998. Constitution and causation in international relations. Rev. Int. Stud. 24:101-17

Wendt A. 1999. Social Theory of International Relations. Cambridge, UK: Cambridge Univ. Press
Whitehead L. 1996. Three international dimensions of democratization. In The International Dimensions of Democratization: Europe and the Americas, ed. L Whitehead, pp. 3-25. Oxford, UK: Oxford Univ. Press

Wiarda H. 1982. Social change, political development and the Latin American tradition. In Politics and Social Change in Latin America: The Distinct Tradition, ed. HWiarda, pp. 3-25. Amherst, MA: Univ. Massachusetts Press. 2nd ed.

Wildavsky A. 1989. Choosing preferences by constructing institutions: a cultural theory of preference formation. In Political Culture and Public Opinion, ed. AA Berger, pp. 2146 New Brunswick, NJ: Transaction 